\title{
P 368
}

\section{Vital Exhaustionとその関連要因に関する検討}

\author{
○渡遥美寿津, 赤松康弘, 古井 景, 渡辺丈貵, \\ M.M.イスラム, 小林章雄（愛知医科大学衛生学）
}

【はじめに】Vital Exaustion (以下V.E.) の意義に関して検討するため,Maastricht Qestionnaire FormB (以下M.Q.) を翻訳し,開発したV.E.調查票日本語版を用い,自記式アンケー 卜調䍒を行い,各要因との関連を検討した.

【対象および方法】N市教職員を対象に調查を行い,V.E.問診票に完全回答の得られた6544名を解 析対象とした(回収率 $65.4 \%$ ，完全回答率 $96.7 \%$ ).対象の内訳は,男性 3327 名（平均年歯 $43.9 \pm 9.8$ 歳,女性3217名 (平均年柃40.2 29.4 歳) であった.V.E. 得点より, 対象者を 4 群 (1: 低得点群, 2: 中 得点群, 3 : 高得点群, 4 :最高得点群) に区分し,各要因との関連について,SAS統計パッケージ Ver.6.12を用い解析・検討した。

【結果】各要因との相関係数を表 1 に示す.V.E.得点と,睡眠時間,病休日数,抑うつ得点,及びJCQ によるデマンド,コントロール,サポート,身体的負荷に有意な関連を認めた.年齢は女性のみに有意 であり,通勤時間との関連は認めなかった.女性は男性と異なり,V.E.得点が高くなるにつれて平均 年柃が有意に上昇していた(図 1).CHD危険因子のうち喫煙に関して検討した結果,女性ではV.E. 高 得点者に喫煙率が高く,男性ではV.E. 高得点者でむしろ喫煙率は低下していた(図 2 ). 高血圧,狭心 症・心筋梗塞, 不整脈, 脳血管疾患を含む循環器疾患との関連では, 男女ともV.E.得点が高くなるに つれ,既往率が高くなる傾向が認められ,女性では有意であった,精神神経疾患との関連では,循環器 疾患と同様,V.E.得点が高い群で，既往率が高く,男女ともに有意であった.対象者のV.E.の背景と して,婚姻・子どもの有無に関して検討した結果,女性では,V.E. 高得点者率は”子どもあり”で高 く,勤労女性のV.E.に育児負担による影響が考えられた。
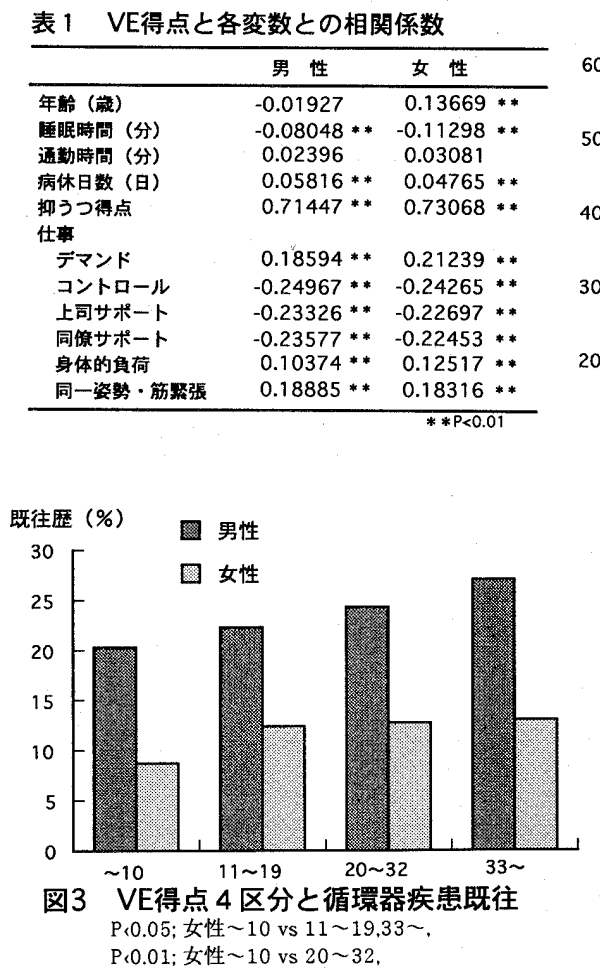

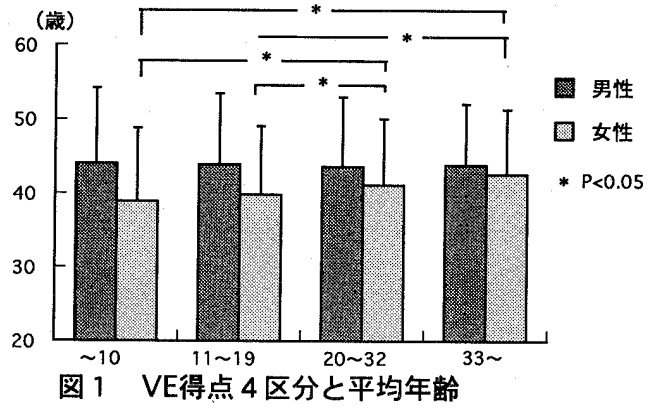

既往魔 (\%)
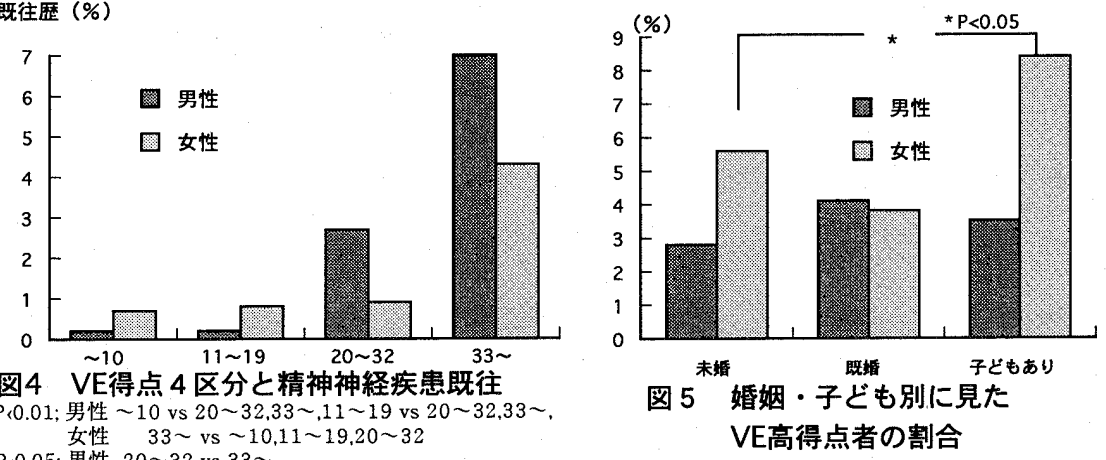

図 5 婚姻・子ども別に見た VE高得点者の割合

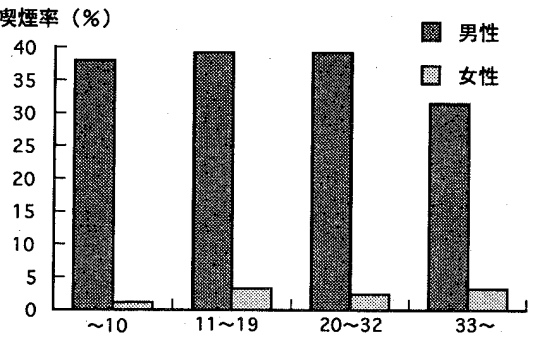

図 2.VE得点 4 区分と喫煙率 P $0.05 ;$ 男性 $\sim 10$ vs $20 \sim 32$, 女性 10 vs $11 \sim 19,20 \sim 32,33 \sim$

女性 $33 \sim$ vs $\sim 10,11 \sim 19,20 \sim 32$ P 0.05 ; 男性 $20 \sim 32$ vs 33 